\title{
Does a University graduate need a portfolio?
}

\author{
Kseniya Mertins ${ }^{1,{ }^{*}}$, Veronica Ivanova ${ }^{1}$, Yury Daneykin ${ }^{1}$, and Natalia Daneikina ${ }^{1}$ \\ ${ }^{1}$ National Research Tomsk Polytechnic University, 634050 Tomsk, Russia
}

\begin{abstract}
Every year an increasing number of employers get interested in the university graduates, most suitable for the requirements the companies set. However, the standard CVs often do not reveal the potential and peculiarities of formation of graduate competences. The authors suggest using portfolio instead of a CV. The authors analyzed 1797 portfolios of TPU students and offered optimal structure and criteria of portfolio. In addition, the authors provide an example of how the achievements reflected in portfolio can be considered. The conclusion is made about the necessity of the portfolio. The authors determined employer's role in the formation and evaluation of the portfolio. Moreover, the value of tracking the dynamics of growth of portfolio components is denoted as a new performance evaluation system in higher education.
\end{abstract}

\section{Introduction}

Modern world has been a global market for quite a long time already. Education is also a product sold around. Therefore, universities around the world should analyze the needs of the modern world to timely offer what students and industry demand [1]. Within two years, students have been enrolled in Russian universities with consideration of the results of their individual achievements, i.e. portfolio compiled during the last school year. The interest of enterprises in the formation of graduates' portfolio is also worth noting. Now the questionnaires offered by employers ask to describe the achievements of graduates in science and social activities apart from GPA - grade point average. The authors consider it possible to continue the practice of formation and evaluation of the portfolio documents in the period of study at the university. This on the one hand, will serve as an additional motivation to the active life position of the students, beginning with the first day at the university, and on the other hand, will help to ensure a more profitable positioning of a graduate (as it contains much more information for employers than the standard CV does).

Many researchers consider the portfolio as a test of formation of graduate competences during training period. According to some authors portfolio allows solving two main tasks: to track individual progress that a student has made in the process of education without direct comparis on with the achievements of other students and to evaluate their educational achievements and supplement (replace) the results of testing and other traditional forms of control. In this case, the outcome document of the portfolio can be viewed as an analogue of a testimonial or of the certificate of test results (or serve along with them).

\footnotetext{
*Corresponding author: mertinskv@tpu.ru
} 


\section{Portfolio peculiarities}

Portfolio of the university graduate is a set of documented learning outcomes (including self-development) submitted for external evaluation and demonstration.

Types of portfolios can be divided according to the type of student activities: study, research, public, etc.

Adriana Baez, Wendy Pacheco and Caroline B. Appleyard distinguish [1] three types of portfolios (career, assessment, and developmental) depending on a variety of functions.

Career or professional portfolios are used to organize, track, store, and maintain documents related to their training and career, included skills, experience, and samples of work or accomplishments, which will supplement the curriculum vitae (CV). Most often, this type of portfolio is made to advance the student who already has experience up the career ladder. Assessment portfolios are only a part of educational program, which provides objective assessment of the graduate learning outcomes for one or another discipline. In addition, this type of portfolio is promising in terms of transition from listing grades in diplomas of higher education to the disclosure of specific skills by giving proof to the level of their formation (the level of formation of competences).

Based on the literature review, the authors believe that portfolio should show different areas of graduate's activity from professional in a certain field to the achievements in the direction, which they choose for self-development. Types of student activity considered in portfolio (learning, research, management, social activities, etc.) are presented in the form of portfolio structure, thus forming a complete image of a graduate.

The portfolio should include nine portfolio parts shown in Table 1, showing individual features of the university graduate. Each part corresponds to results, assessment part and assessment object. Part 1, named «Personal information» is provided by curriculum vitae. A curriculum vita is typically sent with a job application. Educational part describes education (academic diplomas modules) and training, hard skills and soft skills (the growth of the student through the educational program). The authors consider it important to supplement academic diplomas modules with enumeration of leading lecturers, scientific adviser of qualification work, as well as consultants. This improves the social responsibility of the subjects of educational activities and is beneficial for University image. Part 2, named «Educational part» includes educational projects (Description and achievements) according to CDIO initiative [3-6].

In addition, the portfolio may be completed by the 10th part - self-evaluation (selfevaluation of soft and hard skills plays a certain role in the formation of the future exp ert), if such skills as reflection, self-analysis etc. are important for employers. Probably, it will be important for graduates is to tell about themselves - their mission, goals, etc. for different stakeholders of portfolio [7].

Stakeholders have different purposes for creating and maintaining of portfolio and the following are among them:

- for employers - the formation of personnel reserve, reduction of adaptation period on the enterprise;

- for a graduate - systematization of individual achievements, designing of individual educational and career path, building map of competences;

- for a student - choice of development path in the university, opportunity to assess the potential for participation in competitions and scholarship programs, self-evaluation and career planning;

- for the university administration - automation of the selection of candidates for a variety of grants, scholarships and competitions, systematization of data on the various student activities, the possibility of scheduling PHD personnel reserve;

- for departments- use of portfolio as a tool to rate students. 
However, despite different objectives there is something in common that brings together all stakeholders and this is an objective assessment that allows completing the most systematic image of graduates having specific competences.

Table 1. Components of a portfolio.

\begin{tabular}{|c|c|c|c|}
\hline $\begin{array}{l}\mathrm{N} \\
\Pi / \Pi\end{array}$ & Portfolio part & Results & Assessment part \\
\hline 1. & Personal information & Curriculum Vitae & - \\
\hline \multirow{3}{*}{2.} & \multirow{3}{*}{ Educational part } & $\begin{array}{l}\text { Education (academic diplomas } \\
\text { modules), Certificates, Certificate } \\
\text { of Higher Education, Web }\end{array}$ & $\begin{array}{l}\text { GPA - grade } \\
\text { point average } \\
\text { Skills }\end{array}$ \\
\hline & & Training & Skills \\
\hline & & $\begin{array}{l}\text { Projects (Description and } \\
\text { achievements ) [2] }\end{array}$ & $\begin{array}{l}\text { Skills } \\
\text { Experience }\end{array}$ \\
\hline 3. & Professional part & Experience, Cases, Internship & Skills \\
\hline 4. & Scientific part & $\begin{array}{l}\text { Research Projects (Description, } \\
\text { achievements and awards) }\end{array}$ & Skills \\
\hline 5. & Social part & $\begin{array}{l}\text { Projects (Description and } \\
\text { achievements ) }\end{array}$ & $\begin{array}{l}\text { Skills } \\
\text { Results }\end{array}$ \\
\hline 6. & Management part & $\begin{array}{l}\text { Personal mobility (universities } \\
\text { transcripts), MOOCs, Open } \\
\text { University certificates, Language }\end{array}$ & $\begin{array}{c}\text { Skills } \\
\text { Level of language } \\
\text { knowledge }\end{array}$ \\
\hline 7. & Entrepreneurial part & Start-up, Patients & Skills, Results \\
\hline 8. & Professional mistakes & $\begin{array}{l}\text { Examples of failures where } \\
\text { solutions were found }\end{array}$ & Experience \\
\hline 9. & Publication activity & Publications ( published articles) & Skills \\
\hline
\end{tabular}

\section{Methodology of portfolio assessment}

Portfolio, as a system of evaluation of educational achievements generally focuses on the assessment methodology. The authors emphasize the necessity to monitor the dynamics of the activity of university graduates using presented portfolio (dynamics of change of portfolio performance - to evaluate progress and assess mastery of skills and concepts or completion of specific tasks and assignments. Employers are involved in portfolio assessment being one of portfolio customers. In addition, employers can comment on the graduates, assess the level of formation of competences, as well as to evaluate the level of scientific work.

Who is involved in the formation of the portfolio? The stakeholders that take part in the formation of the portfolio. Participants may vary depending on the specialization of the university, student activities, logistics and ecological environment within the university, practice-oriented training of university graduates, etc.

Portfolio can be used for student's assessment, including competition of the scholarship programs of enterprises.

Section "Publication activity", which may be one of the criteria for assessment of the applicant for a scholarship from the company, can be assessed using TPU system 
«Flamingo», which helps to rank publications by significance, by type of publication, etc. Presentations at international conferences weigh 12 points, presentations at Russian conference are given 10 points, conference abstracts -5 points, articles in scientific journals indexed by Web of Science and Scopus international database - 75 points, articles in peerreviewed journals from the list of HAC, indexed by Russian database "Russian Index of Scientific Citation" - 75 points. Thus, it is possible to select which parameters are suitable for selection in each scholarship competition.

In addition, the following criteria are proposed for portfolio:

1. Online access.

2. Relevance of sections to information requested by employers .

3. Consistency, completeness of the description of achievements.

4. Using the rules of grammar and punctuation, language (writing skills).

5. Usability.

6. Confirmation of the results by a tutor, s cientific supervisor, other stakeholders .

7. The possibility of evaluation by external experts in the process of work with the portfolio (evaluation by accredited experts).

8. Integration with University databases (including feedback).

9. Registering the dynamics of indicators growth in the framework of portfolio components (time span- annually).

\section{Results: statistics}

Analysis of work in the system "Flamingo" in TPU confirms the necessity of portfolio management. In April 20161797 portfolios (without division into bachelors, masters and PhD students) were recorded.

Participation of students in 94 competitions of scientific-research work and scholarship programs, 12 Olympiads and competitions of educational achievements were organized from February 1, 2015 until March 1, 2016.

More than 7000 students of 1-4 years of study and more than 1,900 Master Degree students do research work.

More than 6000 students of TPU take part in practical training annually, more than 67 percent of students do practical work in organizations and enterprises.

More than 25 percent of the results performed in students' qualification works, including more than 36 percent of the results of Masters' qualification works are recommended for implementation due to the practice-oriented approach to the implementation of work.

TPU plans to issue portfolio as Diploma Supplement, modifying «Flamingo» system, adding existing sections on the scientific and educational activities.

Thus, TPU can help personnel services of enterprises in the study of documen ts of more than 1,500 graduates. More than 1,500 graduates will annually receive a diploma supplement in the form of portfolio, including the passport of formed competencies, achievements in scientific, educational, creative and sporting activities.

\section{Conclusions}

Portfolio allows considering not only the level of professional competences of students, but also the level of comprehensive self-realization of students in educational environment. The introduction of the portfolio in the university allows not on ly using of modern technologies in training and education, but also developing of motivation to competence, linguistic and professional mobility.

The following risks should be mentioned: 
- openness of information networks (personal data protection);

- necessity to involve all the students;

- opportunity to influence the process of assessment and rating;

- quantitative rather than qualitative approach to portfolio development.

The main problems in construction of the objective student profile in the form of portfolio are regularity of completion, reliability, objectivity in portfolio assessment.

In addition, portfolio systemizes student activities.

\section{References}

1. The Graduate Student Portfolio - Organize and Energize Your Career Development URL:http://www.the-aps.org/forum-portfolio.

2. M. Solovyev, I. Abrashkina, D. Kan, Matec Web of Conf. 48, 06001 (2016)

3. Y. Daneykin, N. Daneikina, Matec Web of Conf. 48, 06003 (2016)

4. K. Mertins, V. Ivanova, N. Natalinova, M. Alexandrova, Matec Web of Conf. 48, $06002(2016)$

5. K. Mertins, V. Ivanova, S. Kaftasev, Matec Web of Conf. 91, 01017 (2016)

6. V. Ivanova, K. Mertins, Matec Web of Conf. 37, 01025 (2015)

7. K. Cote, T. Emmett, Theory into Prac. 54 I 4, 352 (2015) 